\title{
Missing the biggest story in the US Surgeon General's report
}

\author{
Ruth E Malone
}

The recent release of the 50th anniversary US Surgeon General's (SG) report on the health consequences of smoking marked a milestone and has garnered extensive press coverage. ${ }^{1}$ The massive document covers many important topics, from the history of the tobacco disease epidemic to the international context within which contemporary tobacco-focused efforts are occurring, including the WHO Framework Convention on Tobacco Control and the implications of trade agreements. Little noted in media coverage to date, however, is the fact that for the first time, the document includes explicit references to 'end game' strategies, and repeatedly calls for endingrather than merely controlling, or reducing the toll from-the tobacco epidemic. This is a signal achievement given that the SG reports always undergo extensive review and vetting before being pressreleased and published as high-profile government documents. It indicates that the US government may finally be ready to move beyond the cautious, politically safe 'preventing youth from starting and helping smokers quit' mentality toward a comprehensive plan to end the epidemic. $^{2}{ }^{3}$ Simply to use the term 'end game' in such a landmark document is to advance its legitimacy and move the official discourse beyond the status quo. Its importance should not be underestimated.

But the report goes beyond merely talking about the idea of an endgame in the abstract. It specifically calls out two promising endgame strategies that could complement the current tobacco control repertoire: lowering the nicotine content in cigarettes to make them less addictive, and instituting greater restrictions on sales, particularly at the local level, 'including bans on entire categories of tobacco products.' Both have been discussed in this journal, ${ }^{4} 5$ and both could be achieved under existing regulatory authorities at the federal and state/local levels, respectively.

Correspondence to Professor Ruth E Malone, Department of Social and Behavioral Sciences, School of Nursing, University of California, San Francisco, San Francisco, CA 94118, USA, ruth.malone@ucsf.edu
It is also of enormous import that the role of the tobacco industry is so prominently featured in the document. Second among the report's 10 major conclusions is: "the tobacco epidemic was initiated and has been sustained by the aggressive strategies of the tobacco industry, which has deliberately misled the public on the risks of smoking cigarettes." The report includes discussions of the tobacco industry's many efforts to thwart strong tobacco control policies. Evidence on the effectiveness of focusing on and denormalising the tobacco industry itself as part of tobacco control campaigns is also mentioned. The US state and federal litigation against the major tobacco companies is discussed in considerable depth. The report quotes liberally from the painstakingly-annotated landmark federal court decision which, based in part on evidence from millions of pages of internal industry documents, found that the major tobacco companies had for decades engaged in fraud and deceit about the harmfulness of their products, the addictiveness of nicotine, low-tar cigarettes, marketing to youth, and the dangers of secondhand smoke. ${ }^{6}$

Yet in what must count as the biggest 'missed story' of the new year in the US, media coverage of the report's findings tended to focus on diseases, not on the calling out of an industry whose products have been designed to increase addiction and in turn, created more disease, another fact noted in the report. That the nation's top medical authority has for the first time used the bully pulpit of the US SG's office to point to an entire industry as the cause of an epidemic is a politically significant phenomenon that ought to have drawn more media attention than the several additional diseases now known to be caused by the single most deadly consumer product ever made. Thus, two remarkable advances in the US government's tobacco control narrative have passed almost unnoticed so far, and advocates have missed opportunities to make this point in interviews.

The inclusion of such strong language about an industry in a government report could be interpreted as another marker of industry denormalisation, ${ }^{7}$ indicating that the industry's political influence is on the wane in the US Let's hope so. But its appearance is also a credit to those honest government agency employees who undoubtedly fought bloody battles to keep it there, even under an administration that is fairly favourable toward tobacco control. Former US SG Richard Carmona, who once said in an unguarded moment that he would favour banning tobacco products, eventually resigned following what he and other SGs later described as extensive political interference. ${ }^{8}$ That this language stayed in the report means something.

But what it means in practice depends on the whole nation, not just federal agencies, a point the report emphasises. It depends on the families who have lost loved ones to tobacco, who understand well why stronger policy measures are needed. It depends upon health practitioners, who need to move past old 'blame the victim' attitudes, make cessation a priority in practice and get their professional organisations behind stronger policy measures. It depends upon researchers to help policymakers interpret the evidence on how the high-impact media campaigns, the $100 \%$ smokefree places, the point of sale policies will save lives and, in the longer term, money. It depends upon the advocates who will help fight tobacco industry interference and move the political narrative forward. It's far from over. But 50 years after a report that changed the landscape of health in the US, and decades after the tobacco companies themselves anticipated it, we may be inching closer to an endgame.

\section{Competing interests None.}

Provenance and peer review Commissioned; internally peer reviewed.

To cite Malone RE. Tob Control 2014;23:91-92.

Tob Control 2014;23:91-92.

doi:10.1136/tobaccocontrol-2014-051586

\section{REFERENCES}

1 U.S. Department of Health and Human Services. The health consequences of smoking: 50 years of progress: a report of the surgeon general. Atlanta, GA: US Department of Health and Human Services, Centers for Disease Control and Prevention, National Center for Chronic Disease Prevention and Health Promotion, Office on Smoking and Health, 2014.

2 Warner KE. An endgame for tobacco? Tob Control 2013;22(Supp 1):i3-5.

3 Smith EA. Questions for a tobacco-free future. Tob Control 2013;22(Supp 1):i1.

4 Benowitz NL, Henningfield JE. Reducing the nicotine content to make cigarettes less addictive. Tob Control 2013;22:114-7. 


\section{Editorial}

5 Malone RE. Tobacco endgames: what they are and are not, issues for tobacco control strategic planning, and a possible US scenario. Tob Control 2013;21(Supp 1):i42-4.

6 United States District Court for the District of Columbia. Amended Final Opinion, U.S.

Department of Justice versus Philip Morris et al.
Civil Action No. 99-2496 (GK). 2006. http:// publichealthlawcenter.org/sites/default/files/ resources/doj-final-opinion.pdf

7 Chapman S, Freeman B. Markers of the denormalisation of smoking and the tobacco industry. Tob Control 2008;17:25-31.
8 Union of Concerned Scientists. U.S. Surgeon General muzzled by political appointees. http://uwwucsusaorg/ scientific_integrity/abuses_of_science/us-surgeon-generalmuzzledhtml. ND (accessed 22 Jan 2014). 